\title{
Los nuevos retos
}

\section{The new challenges}

\section{Oscar Gerardo Banegas Gonzáles.*}

Cuando preparamos el tiraje de un nuevo ejemplar de nuestro bien amado órgano de difusión del posgrado de pediatría, nos esforzamos por alcanzar los requisitos que nos den final cabida en el singular grupo de los escritos médicos reconocidos y publicados en los buscadores cibernéticos y finalmente indexados. La selección de los autores no es difícil ya que ésta es la tribuna de quienes se preparan para ejercer la pediatría como su vocación profesional y de servicio en la Universidad Nacional Autónoma de Honduras en el Valle de Sula; sus ofertas crecen en la medida que el trabajo científico madura y consigue no sólo plantearse los problemas, definir las hipótesis y sus variables, escoger la metodología y recolectar los datos; para finalmente, compartir los resultados con la comunidad médica y asociada.

El presente número le ofrece bajo el epígrafe Sistema Neuroendócrino, tres investigaciones originales acerca de sendos problemas que aquejan a nuestra población y a nuestros servicios de salud; la primera convulsión en Niños, una inusitada y frecuente neuro emergencia que no deja a pesar de los protocolos bien establecidos de causar ansiedad a profanos y expertos; la Cetoacidosis Diabética, complicación frecuente del creciente número de pacientes con Diabetes Mellitus en la edad pediátrica y; la Trombosis de Senos Venosos Cerebrales, entidad de reciente hallazgo entre nosotros y de importante impacto para pacientes y sus familias. También se da a conocer un trabajo

* Director Administrativo APH

Dirigir correspondencia a: drobanegaspediatra@gmail.com Recibido: 22 de enero 2016 Aprobado: 01 de abril 2016 científico elaborado en el Instituto Hondureño de Seguridad Social sobre cardiopatia en el paciente pediátrico.

Recoge además los interesantes reportes de Enfermedad de Orina olor a jarabe de arce, entidad endócrina poco conocida y de menor frecuencia de notificación; el Síndrome de Rett y el Retraso Puberal igualmente presentes en nuestra población con quizá un sub diagnóstico. Todo producto de la casuística autóctona y el interés investigativo de sus autores que descubren, enriquecen y comparten sus hallazgos en el diario quehacer de la práctica pediátrica en nuestros centros de atención y formación locales. Para concluir se ofrecen las imágenes de un mielo meningocele plano y un lipoma de cono medular, vistas logradas con la anuencia responsable y ética para compartir con el lector algo más de la realidad nuestra; en fin un esfuerzo por superar las entregas previas con temario relacionado: Neuro Endocrinología y a la vez diverso, pulcritud literaria y apego científico.

Lo que nos resta es invitarlos a nuestra tribuna, a través de la dirección de correo electrónica, actapediátrica@unah.edu.hn, esperamos sus comentarios y críticas, sus aportes científicos y por qué no su próxima participación como asesor, co autor o par revisor. Nuestra empresa está en marcha a la búsqueda de la excelencia en la formación de pediatras y de una publicación médica de óptimo nivel fruto de nuestro acervo científico y el denodado empeño de nuestros profesores, ex alumnos, colegas institucionales y nuestros apreciados residentes de pediatría. 